\title{
Pesantren Religious Paradigm: Aqeedah, Plurality, and Jihad
}

\author{
Arifinsyah $^{1 *}$, Ryandi $^{2}$, Manshuruddin $^{3}$ \\ ${ }^{1,2,}$ Department of Religion Studies, Faculty of Ushuludin and Islamic Studies, Universitas \\ Islam Negeri Sumatera Utara Medan \\ Jalan William Iskandar Ps. V, Medan Estate, Medan, Indonesia \\ Email: ryanasofee@gmail.com \\ Email: faihu@pancabudi.ac.id \\ Email: manshurdin@dosen.pancabudi.ac.id
}

\begin{abstract}
The purpose of this study is to describe analytically pesantren religious paradigm in North Sumatera, by tracing their teaching of Aqeedah, plurality, and jihad. The study focuses on two pesantren which are considered as the largest pesantren, they are MusthafawiyahPurbabaruMandailing Natal and RaudhahHasanah Medan. Quantitatively, both pesantren have more than 1000 entries, which come from various regions of Sumatera, and even outside it. The former was the oldest traditional (salafiyah) pesantren in North Sumatera while the latter was one of the earliest pesantren in which the system refers to the modernity of Pondok Modern Darussalam Gontor. The method is qualitative research. Interview, observation, and document analysis were used to collect data. This study has found that two pesantren educated their students with moderate values. It can be seen from: First, their Aqeedah teaching mostly refers to the theological school of Asy'ari and Maturity. These two schools of theology are considered as a moderate school by contemporary moslem scholars, and as majority school of ummah in Indonesia. Second, plurality according to them is a necessity. Moslem has to seek for peaceful co-existence and mutual tolerance between the people of different religions and cultures. Third, the term jihad to them is not only in a physical war but also in intellectual, against lust and doing creative work in society.
\end{abstract}

Keywords: north Sumatera; pesantren; religious paradigm 


\begin{abstract}
Abstrak
Tujuan dari penelitian ini adalah untuk mendeskripsikan paradigma agama pesantren secara analitis di Sumatera Utara, dengan menelusuri ajaran mereka tentang aqidah, pluralitas, dan jihad. Studi ini berfokus pada dua pesantren yang dianggap sebagai pesantren terbesar, yaitu Musthafawiyah Purbabaru Mandailing Natal dan Raudhah Hasanah Medan. Secara kuantitatif, kedua pesantren memiliki lebih dari 1000 santri, yang berasal dari berbagai daerah di Sumatera, dan bahkan dari luar. Yang pertama adalah pesantren tradisional tertua (salafiyah) di Sumatera Utara, sedangkan yang terakhir adalah salah satu pesantren awal di mana sistem mengacu pada modernitas Pondok Modern Darussalam Gontor. Metode yang digunakan adalah penelitian kualitatif. Wawancara, observasi, dan analisis dokumen digunakan untuk mengumpulkan data. Studi ini menemukan bahwa dua pesantren mendidik murid-murid mereka dengan nilai-nilai moderat. Hal ini dapat dilihat dari: Pertama, pengajaran Aqidah mereka sebagian besar merujuk pada sekolah teologis Asy'ari dan modern. Kedua aliran teologi ini dianggap sebagai kelas moderat oleh para cendekiawan muslim kontemporer, dan sebagai mayoritas umat di Indonesia. Kedua, pluralitas menurut mereka adalah keharusan. Umat Islam harus mencari ko-eksistensi damai dan toleransi timbal balik antara orang-orang dari agama dan budaya yang berbeda. Ketiga, istilah jihad bagi mereka tidak hanya dalam perang fisik tetapi juga dalam pengembangan intelektual, melawan nafsu dan melakukan pekerjaan kreatif di masyarakat.
\end{abstract}

Kata kunci: Sumatera utara, pesantre, paradigma agama 


\section{INTRODUCTION}

In general, the paradigm can be defined as the basic way of perceiving, thinking, valuing and doing associated with a particular vision of reality. It is related to someone's worldview including religious behavior. As we knew, education is the most important instrument that builds a paradigm. If the educational institution taught their student radical religious values, it tends to chauvinism. Recently in the Indonesian Moslem community, there are at least three Islamic religious paradigms: first, radical, it is the religious opinions and behavior of people who favor extreme changes especially in government. AlwiShihab views that the paradigm as the theological root of terrorism (Bernard Adeney Risakotta 2014). Second, moderate, it is a term that occurs as an interpretation of the Islamic concept of wasathiyah or wasat (the middle way, center, balanced, best) used in the Quran (la if rathwa la tafrith). Moderate Muslims placed the religion as "state advisor" and the state as "protector of religion". Third, secular. Harvey Cox defines it as the liberation of man from religious and metaphysical tutelage, the turning of his attention away from other worlds and towards this one(Al-Attas 1993). Secular Moslem separated the state from religious values, and placed the diversity of religions in the context of "religious pluralism".

In the context of Indonesians, the word pesantren is often understood as a simple shelter for students who are far from where they live (Thohir 2017). As Indonesia's indigenous educational Islamic institution, Pesantren which is initiated and developed by Muslim scholars (Ulama) have played an important role in the field of education among the Indonesian community. Pesantren can be defined as a place of education and teaching that emphasizes Islamic religious instruction and is supported by permanent santri residences (Fuad 2012). Through boarding schools, the values of morality can be realized (Makhsun 2018). The existence of pesantren has contributed in the course of the nation's history (P.W 2013). This paper will explore Pesantren religious paradigm in North Sumatera, one of the largest multicultural provinces of Indonesia. For the year of 2012, there were 262 pesantrens which accommodated almost hundreds of thousands santris (students). Therefore, it is no doubt that this institution plays an important role, particularly in building religious paradigm of Muslim community in North Sumatera. Among those, Mustafawiyah Purba baru (PMP) in Mandailing Natal, and 


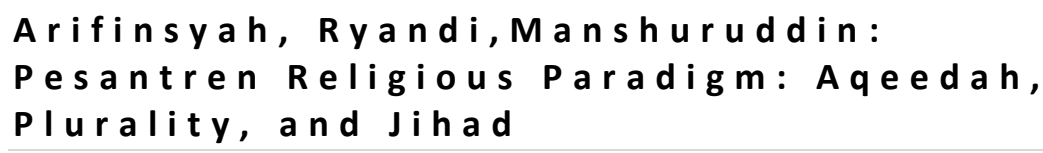

RaudhahHasanah (RH) in Medan Tuntungan were the largest pesantrens which quantitatively have more than 1000 santris. The former is the oldest traditional (salafiyah) pesantren while the later is one of the earliest pesantren in North Sumatera which the system refers to the modernity of Pondok Modern Darussalam Gontor-Ponorogo (PMDG) East Java. In order to give a comprehensive understanding about both pesantren religious paradigms, this study will be focused on three things: 1) Aqeedah, it is by examining their aqeedah literature used; 2) Plurality, both in religious diversity and schools (mazhab); and 3) Jihad.

Indonesia is not only known as a pluralistic society, but also as a Muslimmajority country. This on the one hand is a strategic condition for the transnational Islamic movement to establish an Islamic State, but on the other hand as a threat to the liberal secular movement for the rise of Islam. This makes the religious paradigm of Indonesian Muslims quite diverse, at least can be simplified in three.

First, is the exclusive radical paradigm.This paradigm rests on truth absolutism in opinions and beliefs which is then followed by hatred and violence against those outside of their opinions or beliefs. In the history of Western civilization, this religious paradigm once dominated in the Middle Ages when the Christian Church declared itself as Power and Sacrament, where the Pope could not be misguided. The head of the Church in this world is the Pope, successor to Saint Peter in the diocese of Rome. The Catholics assert that there is no salvation outside of the Church and Jesus Christ. Alan Race, in his book Christians and Religious Pluralism: Patterns in the Christian Theology of Religions, first published in 1983, states that "The exclusivist maintains that salvation is given only to those who make an explicit commitment to Jesus Christ". The opposite people are called heresy and are punished in an institution of Inquisition.

In the history of Islamic civilization, this paradigm has emerged in the age of shahabah-by a group of theological schools called khowarij. Muslims who do not agree with them are kafir, and deserve to be fought. This is based on a textual understanding of religion text. In Indonesia, the emergence of many suicide bombings that occurred in the 2000s was based on this paradigm. 
The second is the moderate paradigm. What we meant by moderate in this study is wasathiyah. The word of Wasath etymologically means something in the middle. In his book Mufradât Al-fâzh Al-Qur'ân, Raghib Al-Isfahani mentions wasath means, "Something that has two ends which are comparable in size." Fakhrudin Al-Râzi mentions that there are several meanings of the word. First, wasath means fair. This is based on qur'anic verses, hadith, and some explanations from sya'ir Arab. Al-Qaffal from Al-Tsauri from Abu Sa'id AlKhudry from the Prophet, says that ummatanwasathan is a just people. Second, wasath means the chosen. Al-Razi chooses this meaning compared to other meanings, for several reasons, among others: this word is the closest to the meaning of wasath and is most more appropriate to, "You are the best people born into humanity "(Qs. Ali Imran: 110). Third, wasath means the best. Fourth, wasath means that religious people in the middle between ifrâth (exaggeration to invent what is new in religion) and tafrîth (reducing religious teachings).

In Indonesia, this paradigm places religion as the giver of values in the state and the state as a protector of religion. In addressing differences, this paradigm recognizes that diversity or plurality is a necessity that cannot be denied, but does not recognize that all religions are the same. Because, in religions there are theological claims that cannot be contested. Every religions has a truth claim, but that does not mean that they may force other religious people into the religion we profess.

Third is the secular paradigm. The term secular emerged in the mid 19th century. This term has been used in the Western world which refers to specific policies towards the separation of Church and State. The word is taken from the Latin "saeculum" which has two connotations, namely time and location. Time shows now or present while location refers to the world. In the New International Webster's dictionary, secularism is related to worldliness and rejects spiritual values while secularize is a process of globalization, a process for secularism: the transition from sacredness to secularism.

In Islamic history, the secular paradigm can be seen from the case of Mustafa Kemal's Turkey which stood on Kemalist Value, namely the six basic principles which became its political philosophy: republicanism, sovereignty and authority based on the wishes of the population. Nationalism, is not based on religion and remains based on the same nationality and serves national ideals. 


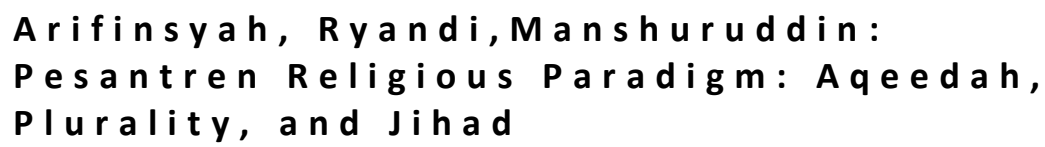

Populism, equality in law, rejecting interests or class disputes, and abuse of capitalism.Ethatism, accepting state interference which is to build the people's economy. Secularism, establishes the separation of religion and state. Revolutionism, accept transformation permanently.

Islamic education which has a function as a medium for the formation of morals, ethics, or students, can be used as a solution for the formation of student character, even this can prevent the emergence of an unjustified act such as acts of terrorism that arise due to radicalism in Islam (Wiyani 2013).

In the study reported by ZaenalArifin (2011) the pesantren paradigm was able to experience a shift due to several reasons (Arifin 2011). First, leadership is centered on one leader, the kyai. Second, it is improvised in methodology. Third, disorientation that causes changes in positioning.

In Indonesia, this paradigm was carried by a group of people calling themselves liberals. They believe that the State must be free from religious values and must stand on the principles of Western democracy and rationalism. In responding to plurality they believe that the source of the conflict that has occurred in Indonesia is due to the truth claim of each religion. For this reason, it is necessary to align the views of all believers that in essence, all religions are the same.

\section{METHODS}

The type of this study is a qualitative research. The object of this study is the religious paradigm of both of PMP salafiyahpesantren and RH modern pesantren. What we meant by qualitative here is a research procedure that produce descriptive data obtained from sources, that through observations and in depth of interviews with informant that have been used as subjects in the study.

The primary data referred to here are data obtained from the results of a combination of observations and in-depth interviews with several key informants, namely PMP Mandailing Natal and RH Medan leaders, administrators and students. This interview was related to the religious paradigm taught in the two pesantren. Secondary data is the sources of the literature that discuss the pesantren and religious paradigms applied in it. The library data can take the form of books, journals, articles, and academic scientific works and so on. 
This research is descriptive analysis. Descriptive analysis aims to describe the fact systematically, factually, and accurately. Data analysis is an attempt to systematically search and organize records of observations, interviews, and documentation to improve understanding of objects and present them as findings for others. Thus, the descriptive analysis in this study is to systematically describe the religious paradigm of PMP and RH Medan.

Pesantren is now seen as an alternative education amidst the weaknesses of formal education (Fadhila 2017). Therefore, pesantren are also required to implement and develop values that are demanded by the community (Ma'arif 2012). Generally, the pesantren education process takes place in a non-classical, where a kyai teaches Islam to santris based on books written in Arabic by early moslem scholars, and santri usually live in pondok (dormitories) in the pesantren (Saifuddin 2015). The Kyai here is the central figure, in which the growth of the pesantren depends on him, while the santri are students who deliberately study at the pesantren, whether they live there or not (Prasodjo 1982).

In the social aspect of Islamic religion, education has a role in developing the potential of human resources (Tatang Hidayat 2018). Since the beginning of its growth, the main function of the pesantren is to prepare students to explore and master the religious knowledge of Islam or better known as tafaqqahuh fi al-din, which is expected to produce cadres of moslem scholar and to educate the Indonesian people and spreading Islam and the people's stronghold in the field of morals. In Islamic boarding schools Islamic knowledge is obtained through recitation, moral guidance through activities carried out in Islamic Boarding Schools (Aulia Nuha Afifatul Istiqomah, Rido Kurnianto 2018).

At least, there are two pesantren systems that have developed in Indonesia. First, traditional (salafiyah), namely pesantren which still retain their original form by merely teaching moslem scholar's works written in 15th century AD. Salafiyah Islamic boarding schools generally reside and carry out religious-based education in the grassroots community (Sumardi 2012). The elements inherent in the traditional pesantren education system are typical Kiai, santri, mosques, huts and the teaching of classical books (Zuhriy 2011). According to Husni Rahim, the SalafiyahPesantren is understood as a pesantren that organizes a non-classical Islamic education system through bandongan and sorogan methods in studying classical Arabic books by scholars in the Middle Ages (Ijudin 2015). The 


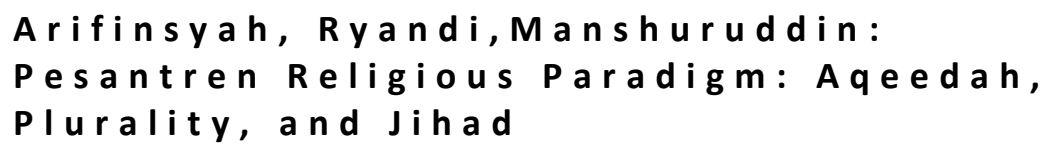

cheeping method is understood as a method of teaching individually, the teacher will give an explanation after one by one student read the book. Furthermore, the teacher's teaching method has a role to explain the book to students (Suyanto 2000).

Institutionally, in the paradigm of the schools of salafi and khalafipontren can be found in the implementation of policies on the use of teaching materials and the objectives of fiqh learning, so that the use of fiqh books in the Shafi'ite school indicates a strict attitude of schooling (Sukarni 2015). The pattern of teaching is "halaqah" system, meaning that the discussion to understand descriptively the contents of the book. Santri believed that the Kyai would not teach the wrong things, and they were convinced that what was being ruled was right. Second, Modern (Khalafiyah). Modern pesantren (Khalafiyah) is an Islamic boarding school that seeks to fully integrate religious knowledge and scientific knowledge. Further, recitation of classical books no longer stands out, some even just complementary, but turn into subjects or fields of study (Masutuhu 1994).

According to Head of the Center for Training Research and Education Development of the Ministry of Religion, Abdul Jamil, up to 2016 the number of santris in 33 provinces throughout Indonesia reached 3.65 million spread across 25,000 pesantren. North Sumatra is one of the provinces that has a very high plurality level. In this area, the development of pesantren is also quite rapid, it is noted that until 2012 there were 262 pesantren both traditional and modern. Among them, Pesantren al-MusthofawiyahPurbabaruMandailing Natal (Madina), and al-Raudhah al-Hasanah (RH) Medan Tuntungan are the two largest pesantren. The first one represents the traditional pesantren style while the second is modern.

\section{RESULTS AND DISCUSSION}

PMP Religious Paradigm. A brief Overview. Pesantren Salafiyah Musthafawiyah Purbabaru was founded in 1912 by Syaikh Musthofa Husein Nasution. After his death (1955), the leadership was continued by his son AbdollahNasution (1955-1995), and then continued by his younger brother Abdul KhalikNasution (1995-2003). From 2003 until now, the leadership was continued by Mustafa BakriNasution, grandson of the founder of the pesantren. From here it 
is clear that there is no provision of leadership tenure. Leadership change only occurs if the previous leader dies.

Since its founding until now, the pesantren has been rapidly developed and grown with thousands of santris, coming from various regions in Indonesia, even abroad such as Malaysia and Saudia Arabia. For the academic year of 2016/ 2017, there were 11.501 santris, with the number of boys: 6.990 and girls: 4.511 . The pesantren educational program is: Salafiyah independent program for nine years, and Indonesian Joint Ministerial Decree (SKB) program for Mts (Madrasah Tsanawiyah) and MA (Madrasah Aliyah).

The motto:

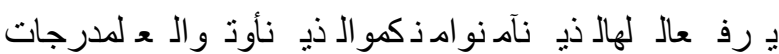

Allah will raise those who have believed among you and those who were given knowledge, by degrees.

The goal:

"Producing moslem scholars (Ulama) who have best morality based on Ahlussunnahwaljama'ah with the Syafi'I School."

The vision:

"Competence in the field of science; Solid in faith; Diligent in worship; Ihsan at all times; Dexterous in thinking; Skilled in religious affairs; Model in the community".

The missions:

1. Continuing and preserving what has been fostered and developed by the founder of Pesantren Musthafawiyah Purbabaru Sheikh MusthafaHusein Nasution to make the pesantren as one of the respected educational institutions in an effort to attain the goodness of the world and the happiness of the hereafter with the framework of Ahlussunnahwaljama'ah (Syafi'i School)

2. Equipment students with all knowledge both of sciences and religions, and particularly the knowledge of prerequisites to I (fard 'aiyn), such as iman, Islam, ethic and the others.

3. To train seriously the santris to be able to read, understand, and interpret the works of previous Moslem scholars or in pesantren tradition usually called "KitabKuning". 


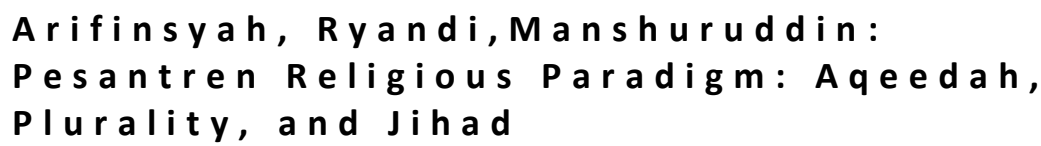

4. Responsible for guiding and familiarizing the santris in worship, zikr, and applying akhalakulkarimah in their daily life both inside and outside the pesantren.

5. With carefulness to explore, and develop the talents of santris so that they have life skills in accordance with the policies and abilities of the pesantren.

6. Carefully and continuously build the personality of santris so that they could be a strong, confident, resilient, honest, and responsible personality, thus they will be able to respond and solve correctly their problem of life.

7. Continuously instilling and fostering the patriotism of students to the nation and state, homeland, particularly towards religion.

Religious ParadigmOnAqeedah.PMP explicitly declared that their Aqeedah is Ahlussunnahwaljama'ah with Syafi'I school. It can be seen to their educational goal, it is to produce moslem scholars who have best manner based on the Ahlussunnahwaljama'ah framework. Further, their literature of Aqeedah mostly refers to Asya'riyah's works and other maturidi's.

Table 1.

Detailed Information of Those Works

\begin{tabular}{|c|c|c|}
\hline Level & Title of Books & Author \\
\hline $\mathrm{I}$ & $\begin{array}{l}\text { Durus al-'Aqa'id al-DiniyahJuz } \\
1 \& \text { II }\end{array}$ & $\begin{array}{l}\text { 'Abd al-Rahman bin Siqaf bin Husein } \\
\text { al-Siqaf al-'Alawi al-Hasani al-Asy'ari }\end{array}$ \\
\hline II & $\begin{array}{l}\text { Durus al-'Aqa'id al-DiniyahJuz } \\
\text { III }\end{array}$ & $\begin{array}{l}\text { 'Abd al-Rahman bin Siqaf bin Husein } \\
\text { al-Siqaf al-'Alawi al-Hasani al-Asy'ari }\end{array}$ \\
\hline III & Fath al-Majid & $\begin{array}{l}\text { Syaikh Muhammad Nawawiibn Umar } \\
\text { al-Jawi al-Syafi‘i }\end{array}$ \\
\hline IV & $\begin{array}{l}\text { Tahqiq al-Maqam 'alaKifayah } \\
\text { al-Awwam fi ma Yajibu } \\
\text { 'Alaihim min al-'Imi al-Kalam }\end{array}$ & Syaikh Ibrahim al-Bajuri \\
\hline V & $\begin{array}{l}\text { al-Husun al-Hamidiyah li al- } \\
\text { Muhafazah 'ala al-'Aqa'id al- } \\
\text { Islamiyah }\end{array}$ & $\begin{array}{l}\text { al-SayyidHuseinAfandi al-Jasri at- } \\
\text { Tarablusi }\end{array}$ \\
\hline $\begin{array}{l}\text { VI \& } \\
\text { VII }\end{array}$ & $\begin{array}{l}\text { Hasyiyah al-DusukialaUmmi } \\
\text { al-Barahin }\end{array}$ & Syaikh Muhammad al-Dusuki \\
\hline
\end{tabular}

Source: From various Asya'riyah's works

The choosing of those literatures is based on the ijtihad of the founder, SyaikhMusthafaHusein. He was a moslem scholar who affiliated with NahdhatulUlama (NU), even he was the first bearer of NU teachings in North 
Sumatra. It is well known that NU is the largest Islamic mass organization in Indonesia which expressly states its theological school Ahlsunnahwaljama'ahAsy'ariyah and Maturidiyah. This is as stated by Ayah Mukhlis Lubis, as Secretary of the Pesantren:

.. the books of the aqeedah that we use are based on ijtihad of the founder of this pesantren, so we are only continuing...we do not dare to change it ... because it relates to something very principle ... and the most relevant to be taught to moslem community in this country. But it should be noted, this does not make the pesantren to be exclusive to other theological schools which are still in the frame of ahlussunnahwaljama'ah ... it's just that the custom of this pesantren requires the asy'ariyah and maturidiyah as the schools of its aqeedah.

From this it can be understood that the reconciliation of the aqeedah school to Asy'ariyah and Maturidiyah was based on the founding ijtihad. This is reasonable, because in the context of traditional Pesantren, the Syaikh or in javanesse tradition called kiyai has the highest authority in determining the direction of the pesantren policy, especially on principle issues in aqeedah.

Furthermore, aqeedah learning is carried out in stages, at the level of 1-2 aqidah learning more to the basic concepts with concise and easily understood Arabic, especially related to al-'Aqoid al-Khomsin which characterizes the learning of aqeedah in the school Ash'ari. Then at levels 3 to 7, the discussion is more detailed in the style of "kitabkuning", because the entire book comes from the writings of early Moslem scholars (salaf). In addition to being taught conceptually about tauhid, those books also taught some schools outside the frame of ahlussunnahwaljama'ah. This is intended to fortify the students' understanding of theological thoughts outside of ahlussunnahwaljama'ah.

On Plurality.For PMP, plurality in terms of ethnicity, nation, religion, etc. is God's will, which must be accepted. The PMP has taught this in terms of the composition of santris which consists of various tribes and cultures. MahmudinPasaribu, as a senior teacher said:

... many people who study here come from various regions ... they live and study together. We are also not picky ... are they Javanese, Mandailing, Malay, we all consider the same ...they are our children. In addition, there is no compulsion to follow the local language here, despite the fact that 


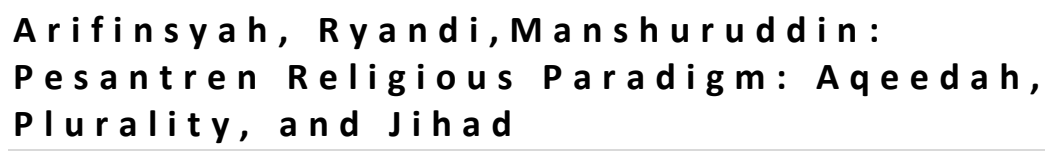

most of santris who have long lived in PMP can speak mandailing ... it is because of their habit of hearing the language of the indigenous people, $\ldots$ there is no structural coercion.

In fact, the santris live comfortably in the pesantren whereas they come from a variety of different backgrounds. Jarwo, a santri from Java said that leaving in Pesantren like at home for the attitude of the teachers was very friendly to anyone regardless of their ethnicity or regions. Conceptually, PMP bases this attitude on the term of ukhuwahfilaqidah (aqidah brotherhood).

It is regarding diversity of religions, PMP expressly stated that Islam is the most true religion while others are heretical. But in this case, someone may not impose their beliefs on others. Even though we have different beliefs but we are brothers in the tern of humanity and nationality. While about the diversity of religious schools (mazahib), PMP expressly stated that Ahlussunnahwaljama'ah is the only true religious school in Islam. In this context, PMP rejects "religious pluralism" which views all religions are equal.

... we respect diversity both in religious belief and schools, but it must be noted that we do not justify religions outside of Islam and sects outside of ahlussunnahwaljama'ah ... like the idea that say that all religions are the same or radicalism say that his view is the only truth and force the truth to others ... because it is related to the problem of principle ... so we reject ... but for the problem of the school of fiqh we choose the syafi school ' That is why we use the books of Syafi'iyah ... but we do not reject or deny the four schools of fiqh ... even in certain conditions we use other schools.

On Jihad.PMP means jihad as being serious in doing something, referring to the etymological meaning of the word jahada-yajhadu. The application of the concept is based on the verse of the Qur'an:

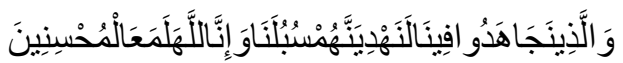

"and those who strive for us- we will surely guide them to our ways. And indeed, Allah is with the doers of good. (Qs. al-Ankabut: 69)

In this context, the meaning of jihad for PMP does not only refer to physical warfare, therefore, in educating santris the association of jihad with physical war is greatly avoided, but it does not mean that it does not justify jihad in the term of war carried out by Muslims against people - infidels who fight 
them. Considering the condition of those who are still students and in a state of peace, the emphasis of jihad is more on the jihad of knowledge and social service. This is as stated by (ayah) Mahmudin Pasaribu:

... the meaning of jihad emphasized here is to study ... and to teach in the midst of society ... that's why we order the final grade or seventh graders to do service in the community ... preaching, taking care of the corpses (bilalmayit), helping those who are in trouble ... we give only that knowledge ... and the people around here have understood that those santris are from PMP...

In addition, PMP also emphasizes jihad against lust through spiritually exercises or riyadhoh. This is the greatest jihad, and as the principal in carrying out other jihads. The exercise was carried out with obligatory deeds and the sunnah that taught in Islam ahlussunnahwaljama'ah.

... the prophet also taught after the end of the war: ... we have finished from small jihad to great jihad ... that great jihad means jihad against lust ... this is our foundation to carry out other jihads which is to stay on its path, namely fi sabilillah. This means that all actions can be said to be a jihad if done seriously and intended to God or we call lillahita'ala.

RH Religious Paradigm.A Brief Overview.RaudhahHasanah Modern Pesantren was initiated in 1986 by UstadzUsmanHusni and his friends. The pesantren is established by the KulliyatulMua'llimin al-Islamiyah (KMI) system refers to the education system of Pondok Modern Darussalam Gontor. Since its founding until now, RH has developed very rapidly. $\mathrm{RH}$ has been led by four Directors, as shown in the following table:

Table 2.

Directors That Have Been Lead RH

\begin{tabular}{lll}
\hline No & \multicolumn{1}{c}{ Name } & \multicolumn{1}{c}{ Period } \\
\hline 1 & Drs. H. Usman Husni & 1986 \\
2 & Drs. H. Magfur Abdul Halim & $1988-2002$ \\
3 & Drs. Sahid Markum, S.Pd.I & $2002-2009$ \\
4 & Drs. Rasyidin Bina, M.Ag & $2009-2016$ \\
5 & Sholihin al-Din & 2016-until now \\
\hline & Source: Modern Islamic Boarding School RaudhahHasanah
\end{tabular}




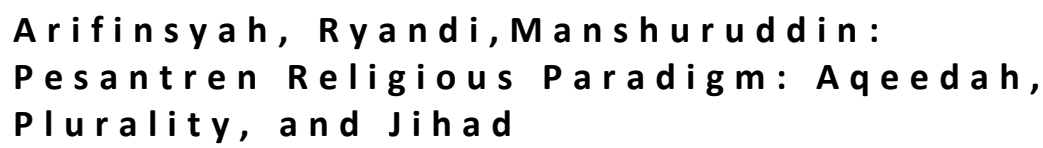

For the academic year 2017/ 2018 there were 3145 santris consisting of boys: 1475 and girls: 1661. Besides that, education model refers to KMI Pondok Modern Darussalam Gontor, RH also used Indonesian Joint Ministerial Decree (SKB) program for Mts (Madrasah Tsanawiyah) and MA (Madrasah Aliyah). All students and students must live in the dormitory.

The Vision:

"Making Pesantren Raudlatul Hasanah as a regeneration institution and quality public services, solely for worshiping Allah Swt and hoping for His blessing and the implementation of the function of the Khalifah Allah on earth."

What we mean by regeneration is the process of producing moslem scholars (ulama) and leaders of ummah which are structurally and simultaneously managed through a conducive environment, as well as services for the development of superior and qualified personal both as academics and practitioners reflected in innovative, creative and proactive attitudes towards the development of science.

The missions:

1. To educate individuals for mastering the basic knowledge of leadership, teaching, and be able to develop optimally themselves.

2. To prepare the superior and qualified personality in order to build the best generation (khairaummah)

3. To produce a moslem scholar who masters religious knowledge (mutafaqqihfiddin) and have a great intellectual tradition that responsive to the progress of the time and its demands towards "learning society"

4. To educate and build a generation of IQRA personalities ('Ilmi, Qur'any, Rabbany and 'Alamy) who are ready to practice it in the midst of society with sincerity, smartness, and charity. Iqra combines aspects of thought ('ilmy 'alamy) and aspects of remembrance (qur'anyrabbany) which are actualized in religious organization and morality.

The PancaJiwa:

1. Sincerity

2. Simplicity

3. Self-reliance

4. Islamic brotherhood 
5. Freedom

The motto:

"Pesantren RH emphasizes the personality of Muslim, Mu'min, and Muhsin that have a noble character, healthy body, broad knowledge, independent mind and doing sincerely. Those are the motto of Pondok Modern."

Religious Paradigm.On Aqeedah.RH modern pesantren curriculum is generally divided into several fields of study, namely: Languages (Arabic and English), Islamic Studies (DirasahIslamiyah), and social and exact sciences. Aqeedah lessons are part of DirasahIslamiyah. The literatures used in aqeedah learning are as follows:

Table 3.

The Literatures Used in Aqeedah Learning

\begin{tabular}{|c|c|c|}
\hline Grade & Name of Books & Author \\
\hline $\mathrm{I}$ & $\begin{array}{l}\text { Ushuluddin ('Aqo'id) } \\
\text { 'AlaMadzhabAhl al-SunnahWa } \\
\text { al-Jama'ah }\end{array}$ & KH. Imam Zarkasyi \\
\hline II & Kitab al-Sa’adah & 'Abd al-RahmanManaf \\
\hline III, IV & ‘Ilm al-Tauhid & $\begin{array}{l}\text { 'Abd al-'Aziz 'Abd al- } \\
\text { Lathif }\end{array}$ \\
\hline $\mathrm{V}, \mathrm{VI}$ & Haqiqah al-Tauhid & Dr. Yusuf al-Qardhawi \\
\hline
\end{tabular}

Source: Modern pesantren curriculum in reproductive health

From here it can be seen that in general, the books refer to Asy'ariyah's thought, but in certain parts, they also refer to salafmoslem scholars such as IbnTaymiyah, especially in the division of tauhid to uluhiyah, rububiyah, and asmawashifat. In addition, most of the textbooks used to refer to contemporary moslem scholars through the selecting and sorting by the teaching team of tauhid. In this context, the teachers are given the freedom to change the subject to adjust to the conditions of the center, with a note that it does not change the basic things in the aqeedah of ahlsunnahwaljama'ah. UstadzImamulAwthon, as division of the pesantren curriculum, says: 
Arifinsyah, Ryandi, Manshuruddin:

Pesantren Religious Paradigm: Aqeedah,

Plurality, and Jihad

$\ldots$ in the class 1 until 4 we are fully learning the Asya'ari school, but in class 5 until 6 we are using contemporary moslem scholar work like Yusuf Qardhawi ... even though he learned the Asya'ari school he also appreciated IbnTaymiyah's view mainly on the division of tauhid ... for several years ago, the study of aqeedah uses IbnTaymiyah's work of aqidahwasithiyah ... according to us, as the teachers here, that is too doctrinal to be studied with children ... so we choose contemporary scholars as an adaptation to the conditions of the students now.

Furthermore, the santris of $\mathrm{RH}$ also studied classical literature of the Asy'ariah scholars; it is studied especially by the santris of religious studies. The reason is that most of the Moslem of the world theologically referred to Asy'ari school. Besides that, Asy'ari school according to them has a rational method in Aqeedah. These characteristics are the main reason why the Asya'ari school was chosen. This is intended so that students can think and behave wiser or in moderate values (wasathiyah). UstadzAndiWahyudi, as Divison of pesantren education system, says:

...we have studied that asya'ri thought is not radical and also not liberal...or we called it moderate...besides that this school also criticizes other views that not in the frame of ahlussunnahwaljama'ah not only based on qur'anic verses but also on logic and structure of thinking... so that easy to be understood.

On Plurality.RH's concept of plurality is based on the philosophy that the Pesantren is standing above and for all groups. This philosophy is applied in a room placement system where one room consists of various regions, and tribes. It aims to foster awareness that we live in a pluralistic region. In addition, the santrisare also not allowed to speak the local language. The official language both Arabic and English. This is intended to minimize the emergence of regionalism in their daily life.

According to RH, Plurality is a necessity referring to the Qur'an Surah: Hud, verse: 118:

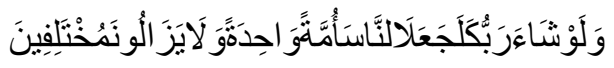

And if your Lord had willed, He could have made mankind one community, but they will not cease to differ. 
The verse shows that mankind is different, in term of belief and so on. However, it should be noted, that the inevitability of diversity is not justifying the faith of other religions outside of Islam or other groups outside the ahlussunnahwaljama'ah. The Qur'an explicitly explained that Islam is the only religion blessed by God. Therefore, theological tolerance or commonly called "religious pluralism" is false tolerance because it assumes that all religions are the same. However, the Qur'an also commands Muslims not to impose their beliefs on others.

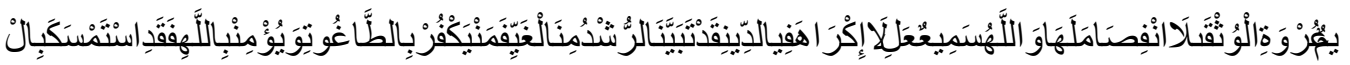

There shall be no compulsion in [acceptance of] the religion. The right course has become clear from the wrong. So whoever disbelieves in Taghut and believes in Allah has grasped the most trustworthy handhold with no break in it. And Allah is Hearing and Knowing.

Those all verses show that Islam taught us to be theologically exclusive and sociologically to respect others. Therefore, what RH means by "stand above and for all groups" is not to theologically justify the heretical groups. Regarding this, UstadzAndiWahyudi says:

...what we mean by "stand above and for all groups" does not justify all groups ... therefore in the motto of Pesantren, before freedom of thinking must be broadly knowledge ... liberals who say all religions are true are people who have an independent mind without broad knowledge.

In understanding such ideality, $\mathrm{RH}$ also taught the santris the heretical schools of thought both classical and contemporary through the studies that guided by teachers (asatidz). There were two groups, namely Afkar Study Club (ASC), and the Turats Study Club (TSC).

Regarding the school of fiqh, $\mathrm{RH}$ is very flexible. This can be seen from the book of fiqh that was studied is BidyatulMujtahid by IbnRusyd. This book contains the views of the school of thought on the problems of Fiqh. However, for the students of religious studies, Fiqh learning mostly refers to shafi'iyah works. It aims at preparing moslem generations who care about the Shafi'iyah school as the majority school of the Indonesian people.

On Jihad.RH Modern Pesantren interprets jihad in term of intellectual. UstadzAndiWahyudi says: 


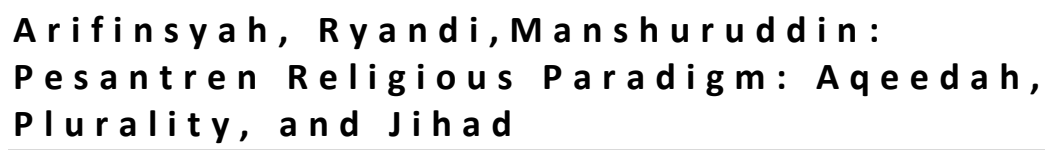

...in this pesantren, jihad for santris means looking for knowledge ... (man khoroja fi thalabilmifahuwa fi sabilillahhattayarji'a) ... struggling in society ... understanding jihad in term of physical war is not compatible for santris, I think it is similar to PesantrenGontor as our guidance...about martial as our extracurricular is intended to physical health and selfdefense ... indeed we don't deny the existence of jihad war but it's not for students here.

Intellectual jihad is not limited to the classroom, but to extracurricular activities in Islamic studies, with the slogan "nahnuqoumunnaqro'uwanaktubu". This means that we are the people who read and write it. The targets of the study are:

1. To motivate santris to love reading book, for the books are the window of knowledge

2. To educate santris how to express their ideas in communicative speech and formal language

3. To build santris writing skill

4. To make the santris care about the reality of the contemporary world

5. To equip the santris all sciences, particularly religious science that most be needed by the people.

In a similar sense, Ahmad ZulhamHamdan, one of the final grade students, says that:

... this pesantren teaches jihad which means struggles, looking for knowledge to uphold the word of laailahaillallah ... hence it is obligatory for us to jihad and not only physical war ... but also like studying, jihad against lust ... and most importantly jihad fights in God's way.

Intellectual jihad is the basis for carrying out other jihad such as struggling in the midst of society because in reality pesantren is established to produce moslem generations as munzirulqoum warning the people to the right path, as stated in the Qur'an:

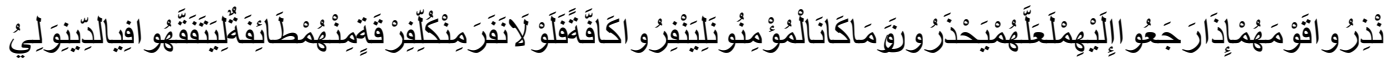
"...And it is not for the believers to go forth [to battle] all at once. For there should separate from every division of them a group [remaining] to 
obtain understanding in the religion and warn their people when they return to them that they might be cautious."

Furthermore, jihad against lust is processed through the pesantren educational system by disciplining the santris to obligatory worship and sunnah. The discipline is through habituation with giving punishment to those who break the law. This is called as militancy to purify the soul.

\section{CONCLUSION}

From this study, it was found that:

1. On Aqeedah. The textbook of Aqeedah used in both pesantren mostly refers to the Asy'ariah scholars. Both of them also expressly stated that their theological school was Asy'ari. The difference that RH modern pesantren has referred to the contemporary ash'ariyah scholars such as Yusuf Qardhawi, while PMP only refers to early Ashariya's scholars. Further, RH chosen Ashy'ariyah as their theological school is due to its rational method in aqeedah, and taught the moderate values that very compatible to be applied in Indonesia as a pluralistic society. While for PMP, making Ashyariyah as their theological school due to an appreciation (adab) toward the founder of the pesantren.

2. On plurality. Both of them recognize the existence of plurality in religion but do not recognize religious pluralism which recognizes that all religions are true. Regarding the religious school, both of them also expressly state that the ahlussunnahwaljama'ah school is the right (haq) and the other is misguided. On the issues of furu'iyahfiqhiyah, they acknowledge the existence of four schools of fiqh and justify all of them, but the PMP states explicitly the Shafi'i school. While at RH, the students were given the freedom to choose one among the schools of fiqh, but in reality, they were more inclined to the Shafi'i school.

3. On Jihad. Both of them interpret jihad widely not only in physical war, but also in intellectual jihad, and fight in society. This refers to the purpose of the pesantren as the Moslem generation who warn the ummah for the good or called the mundzirulqoum.

The conclusion shows that both pesantrens taught their santris with moderate values. It is because of their Aqeedah teaching mostly refers to the 


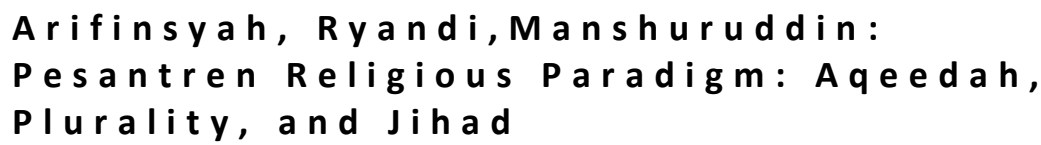

theological school of Asy'ari and Maturidy. These two schools of theology are considered as a moderate school by contemporary moslem scholars, and as majority school of ummah in Indonesia. Plurality according to them is a necessity. Moslem has to seek for peaceful co-existence and mutual tolerance between the people of different religions and cultures. And the term jihad to them is not only in a physical war but also in intellectual, against lust and doing creative work in society.

From this, the writers recommend to the government of North Sumatra to synergize with the world of pesantren in realizing a moderate religious paradigm. Wallahua'lam...

\section{REFERENCES}

Al-Attas, Syed Naquib. 1993. Islam and Secularism. Malaysia: ISTAC.

Arifin, Zaenal. 2011. "Pergeseran Paradigma Pesantren.” Jurnal Pergesaran Paradigma Pesantren 22(01):43-60.

Aulia Nuha Afifatul Istiqomah, Rido Kurnianto, dan Anip Dwi Saputro. 2018. "Manajemen Pesantren Mahasiswa Dalam Membentuk Karakter Religius Di Pesantren Mahasiswa Al-Manar Universitas Muhammadiyah Ponorogo.” Jurnal TARBAWI 02(02):12-25.

Bernard Adeney Risakotta, Ed. 2014. Dealing with Diversity: Religion, Globalization, Violence, Gender, and Disaster in Indonesia. Yogyakarta: Indonesian Consortium for Religious Studies.

Fadhila, Lita Nala. 2017. "Pendidikan Alternatif Dengan Model Pesantren SalafiKhalafi (Studi Mengenai Sistem Pendidikan Di Komplek R2 Pondok Pesantren Al-Munawwir Krapyak)." Jurnal Kajian Kependidikan Islam 02(01):1-20.

Fuad, A. Jauhar. 2012. "Pendidikan Karakter Dalam Pesantren Tasawuf.” Jurnal Pendidikan Karakter 23(01):60-77.

Ijudin. 2015. "Pengembangan Konsep Mutu Pendidikan Pondok Pesantren." Jurnal Pendidikan 09(01):15-32.

Ma'arif, Syamsul. 2012. "Transformative Learning Dalam Membangun Pesantren Berbasis Multikultural.” Jurna Pengembangan Pendidikan 01(01):58-71.

Makhsun, Samsudin Salim dan Toha. 2018. "Manajemen Pesantren Mahasiswa (Studi Kasus Manajemen Pesantren Aji Mahasiswa Al-Muhsin 
Yogyakarta).” Jurnal Studi Dan Penelitian Pendidikan Islam 01(02):58-64.

Masutuhu. 1994. Dinamika Sistem Pendidikan Pesantren, Trans: The Dynamic of Pesantren System. Jakarta: INIS.

P.W, Dhevin M. .. dan Agus. 2013. "Manajemen Pondok Pesantren Dalam Mengintegrasikan Kurikulum Pesantren Dengan Pendidikan Formal.” Jurnal Edu Islamika 05(02):190-225.

Prasodjo, Sudjoko. 1982. Pesantren. Jakarta: LP3ES Rizter.

Saifuddin, Ahmad. 2015. "Eksistensi Kurikulum Pesantren Dan Kebijakan Pendidikan.” Jurnal Pendidikan Agama Islam 03(01):208-34.

Sukarni. 2015. "Paradigma Bermazhab Pondok Pesantren Di Kalimantan Selatan.” Jurnal Miqot 39(01):78-93.

Sumardi, Kamin. 2012. "Potret Pendidikan Karakter Di Pondok Pesantren Salafiah.” Jurnal Pendidikan Karakter 02(03):280-89.

Suyanto, Zamakhsari dan. 2000. "Efektivitas Pembelajaran Di Pesantren Mahasiswa (Studi Kasus Di Pesantren Aji Mahasiswa Al Muhsin Yogyakarta).” Jurnal Penelitian Dan Evaluasi 02(03):157-70.

Tatang Hidayat, Ahmad Syamsu Rizal dan Fahrudin. 2018. "Pola Pendidikan Islam Di Pondok Pesantren Mahasiswa Miftahul Khoir Bandung Dalam Membentuk Kepribadian Islami.” Jurnal Pendidikan Islam 07(01):357-69.

Thohir, Kholis. 2017. "Kurikulum Dan Sistem Pembelajaran Pondok Pesantren Salafi Di Kecamatan Kresek Kabupaten Tangerang Provinsi Banten.” Journal Anaytica Islamica 06(01):11-20.

Wiyani, Novan Ardy. 2013. "Pendidikan Agama Islam Berbasis Anti Terorisme Di SMA.” Jurnal Pendidikan Islam 02(02):65-83.

Zuhriy, M. Syaifuddin. 2011. "Budaya Pesantren Dan Pendidikan Karakter Pada Pondok Pesantren Salaf." Jurnal Walisongo 19(2):287-310. 